Boise State University

ScholarWorks

Criminal Justice Faculty Publications and

Presentations

Department of Criminal Justice

4-1-2009

\title{
He Versus She: A Gender Specific Analysis of Legal and Extralegal Effects on Pretrial Release for Felony Defendants
}

Jeremy Ball

Boise State University

Lisa Growette Bostaph

Boise State University 


\title{
He Versus She: A Gender Specific Analysis of Legal and Extralegal Effects on Pretrial Release for Felony Defendants
}

\begin{abstract}
The current study seeks to identify significant predictors of pretrial processing for both male and female defendants in an aggregate sample. The data used in this study is taken from the State Court Processing Statistics (SCPS), 1990-2000: Felony Defendants in Large Urban Counties (Bureau of Justice Statistics 2004). The original sample included a total of 87,437 felony cases. The relationship between relevant independent variables and five separate dependent variables (denial of bail, non-financial release, amount of bail set, making bail, and pretrial incarceration) were analyzed using both multivariate regression and Z-score comparisons within gender-specific models. Findings suggest that effects of certain independent variables on pretrial release decisions and outcomes are different between the gender-specific models.
\end{abstract}

Jeremy D. Ball, JD, PhD

Boise State University

Lisa Growette Bostaph, PhD

Boise State University

KEYWORDS: pretrial release, bail, gender differences, disparity, discretion

\section{INTRODUCTORY NOTE}

Jeremy D. Ball is an Assistant Professor in Criminal Justice at Boise State University. He earned his J.D. from the Indiana University School of Law in Indianapolis and his Ph.D. from the University of Nebraska-Omaha. His research interests are in the areas of court processing decisions and prosecutorial discretion. Jeremy has been published in the Journal of Ethnicity in Criminal Justice, Journal of Contemporary Criminal Justice, Criminal Justice Policy Review, Criminal Justice Studies, and Journal of Family Issues. Dr. Ball also has a chapter entitled "Sentencing Reforms and the Supreme Court: The Implications of Apprendi, Blakely, and Booker" in Legal Issues in Criminal Justice edited by Craig Hemmens.

Lisa Growette Bostaph is an Assistant Professor of Criminal Justice at Boise State University. Dr. Bostaph holds a Ph.D. from the University of Cincinnati. Her research interests include racially-biased policing, police effectiveness, and women and crime. Dr. Bostaph has been published in the Security Journal, Journal of Criminal Justice, Journal of the Ethnicity and Criminal Justice, and Policing: An International Journal of Police Strategies and Management. Dr. Bostaph also coauthored a chapter with Dr. Mary Stohr entitled "Current Issues in the Law and Women: WWARWD?" in Women, Law, and Social Control ( $2^{\text {nd }}$ Edition) edited by Alida Merlo and Joycelyn Pollock.

\section{INTRODUCTION}

Researchers have historically overlooked female offenders in the criminal justice system. Women, while included in criminological and criminal justice research, were primarily discussed in terms of victims and/or relatives of male offenders (Belknap 2001). Only in the past 20-25 years have researchers begun to study, in earnest, women as offenders in the criminal justice system (Belknap 2001). Early research focused primarily on juvenile offenders (Belknap 2001). But, two factors sparked interest in the field of female offenders: the increasing number of both feminist scholars in criminology and criminal justice and female offenders entering the criminal justice system. 
This is a preprint of an article whose final and definitive form has been published in the Women and Criminal Justice @ 2009 [copyright

Taylor \& Francis]; Women and Criminal Justice is available online at: http://www.informaworld.com doi: 10.1080/08974450902791286

Feminist scholars have contributed greatly to current understandings of female offending (both adult and juvenile) and conditions inside women's prisons. Other criminal justice researchers have become interested in female offenders due to the increasing numbers of women entering the criminal justice system since the mid-1980s (Belknap 2001).

\section{LITERATURE REVIEW}

\section{Prevalence and Extent of Female Offending}

Between 1996 and 2005, drug violations, embezzlement, and vagrancy showed the greatest percentage increase for both men and women between 1996 and 2005. But, in the past five years, the offenses with the greatest percentage increase have diverged for men and women. For both genders, vagrancy saw the largest increase $(+24.9 \%$ for men, $+32.5 \%$ for women), but, from there, differences arise. Suspicion and weapons charges are the second and third largest percentage change for men $(+23 \%$ and $+19.8 \%$, respectively). Drug violations and stolen property charges demonstrated the largest percentage change for women $(+24.8 \%$ and $+21.9 \%$, respectively) (FBI 2006). According to the 2005 Uniform Crime Reports (FBI 2006), the five most frequent crimes for which males were arrested were all other offenses (except traffic), drug violations, driving under the influence, other assaults, and larceny-theft. For female offenders, the five most frequent offenses were all other offenses (except traffic), larceny/theft, drug violations, other assaults, and driving under the influence. There were only two offenses where female offenders equaled or outnumbered male offenders: embezzlement and prostitution charges.

While differences between the most frequently committed offenses for female and male offenders are minimal, the difference in the extent of offending is considerable (FBI 2006). In 2005, female offenders accounted for only $23.8 \%$ of all arrests. Even so, the number of women arrested increased at a much faster pace than for men. From 1996 to 2005, the total number of women arrested increased 7.4\%, while the total number of men arrested decreased $7.6 \%$. The total number of arrests of women increased at an even higher rate during the past five years $(+9.5 \%)$ compared to men $(+1.7 \%)$ (FBI 2006).

These same trends were found in the one-day counts of jail inmates. In a one-day count of jail inmates in the United States, in $2005,86.3 \%$ of jail inmates were male, $12.9 \%$ were female, and $.8 \%$ were juveniles of either gender (Sabol, Minton, \& Harrison 2007). During the same ten year period (1996-2005), the number of adult male jail inmates increased by $42 \%$, while the number of adult female jail inmates increased by $69 \%$ (Sabol, Minton, \& Harrison 2007).

Discretion and Disparity in Court Processing Decisions

Discretion is pervasive in the criminal justice system today. Discretion provides efficiency in case processing (Packer 1968; Gottfredson \& Gottfredson 1988), certainty in outcomes (Albonetti 1987), and independence in decisionmaking (Gottfredson \& Gottfredson 1988). Discretion allows criminal justice officials to make decisions tailored for each individual to avoid rigid, formal rules (Cox 1976; Spohn 2002). Discretionary decisions in the criminal justice system are abundant, including the decisions to arrest, release prior to trial, negotiate a guilty plea, and the type and length of sentence. In fact, discretion is more likely at earlier stages of the criminal court processes due to low visibility and less restrictive rules and procedures (Hagan 1974; Steffensmeier 1980).

One of the major effects of discretionary decision-making in the criminal courts today is disparity. Walker (1993:146) concluded, "The single most important achievement for criminal justice in the last thirty has been the recognition of the problem of (unfettered) discretion". Scholars agree that such discretion has great potential to lead to discrimination - or, unwarranted disparity (see Walker, Spohn, \& DeLone 2003). Scholars have suggested that the disproportionate representation of certain groups - namely, racial/ethnic minorities - can be attributed to discretion in sentencing (Johnson, 2005; Spohn 2002; Steffensmeier, Ulmer, \& Kramer 1996). Blumstein, Cohen, Martin, and Tonry (1983) suggested, though, that some of the unwarranted disparity found in prison populations could be attributed to a cumulative process whereby discretionary decisions at each stage contribute to the overall overrepresentation of certain groups in the prison population. If some of the disparity that has existed in prison populations can be attributed to early decision points, then research is needed to study these potential effects. A decision point that is likely to contribute to this overall cumulative disparate effect is the pretrial release decision. 
This is a preprint of an article whose final and definitive form has been published in the Women and Criminal Justice (0) 2009 [copyright

Taylor \& Francis]; Women and Criminal Justice is available online at: http://www.informaworld.com doi: 10.1080/08974450902791286

Disparities in Pretrial Release

Pretrial release is a decision that relies heavily on judicial discretion in terms of not only releasing the defendant but also of the type and amount of financial release. The decision to release the defendant prior to trial not only depends on the perceived likelihood of the defendant's return to court but also on the perceived dangerousness of the defendant to the community (Goldkamp \& Gottfredson 1979; see also Stephensmeier et al., 1998).

Several researchers have examined unwarranted disparities in pretrial release decisions. Until recently (Demuth 2003; Schlesinger 2005), research has only focused on a few of these decisions due to limited resources or theoretical considerations of other stages of the pretrial release process (Albonetti 1989; Nagel 1983; Steury \& Frank 1990). Nagel (1983), for example, identified the pretrial release process as a three-step process: whether or not to release on own recognizance, financial amount of bail, and whether or not there was a cash alternative (e.g., $10 \%$ bail).

It is important to note that pretrial release has an impact on later court processing decisions (e.g., sentencing and sentencing length). Offenders who spend time in jail before trial are more likely to spend time in incarceration after trial (Chiricos \& Bales 1991). Demuth (2003:876) suggested that, "pretrial detention is punishment before conviction." Scholars have identified the need to examine potential disparities in judicial decisions on pretrial release. Pretrial release decisions rely on a strong discretional authority that is often less scrutinized than the discretional authority utilized in sentencing decisions (Demuth 2003). As the opportunity for discretion increases, the potential for unwarranted disparities increase. Spohn and Cederblom (1991) found that black defendants were more likely than white defendants to be detained prior to trial and more likely to be tried before a jury. Those who have their cases heard by a jury are more likely to be treated more harshly than others who plead guilty (Brereton \& Casper 1981-1982; Britt 2000). This phenomenon has been characterized as the "jury trial penalty" (Ulmer 1997). Examining the potential disparities in pretrial release decisions, therefore, is relevant.

Studying the potential disparate effect of extralegal factors on pretrial release decisions, therefore, is also relevant due to its effect on later decisions - namely, sentencing. Spohn, Gruhl, and Welch (1981-1982) conducted a path analysis linking charging and pretrial release decisions to sentencing decisions. They found that race did not directly relate to sentencing decisions but rather had an indirect effect through other operations such as pretrial release. Black males were less likely to be released prior to trial and, therefore, were sentenced more harshly than white males (Spohn et al. 1981-1982). Pretrial release decisions operated as a contextual effect through which race impacts sentencing decisions. Their focus, though, was on indirect effects of pretrial release decisions on sentencing decisions; their intention was not to focus on disparities in pretrial release decisions. Most of this current line of research notes that legal factors - that is, offense severity and prior criminal history - were the strongest predictors of the several pretrial release decisions (Demuth 2003; Demuth \& Steffensmeier 2004; Schlesinger 2005). Scholars, though, have found that race and ethnicity had significant effects on pretrial release decisions (Demuth 2003; Demuth \& Steffensmeier 2004; Schlesinger 2005).

Recently, research has identified more robust measures of the pretrial release decision and better techniques to identify potential racial/ethnic disparities in these decisions. In fact, Demuth (2003) recently characterized these definitions as either pretrial release decisions or pretrial release outcomes. Pretrial release decisions are the decisions to deny bail (or, preventive decision), to give a financial release if release was granted, and to determine the amount of financial release. Pretrial release outcomes are whether the defendant could pay the financial release or not and the detention status of the defendant (i.e., detained or released) (Demuth 2003; Schlesinger 2005). The recent literature on unwarranted disparities in pretrial release decisions is organized by the pretrial decisions and outcomes identified by Demuth (2003).

Decision to Deny Bail

In estimating the effects of race and age on pretrial release decisions, Demuth (2003) examined felony cases in 40 of the most populous 75 counties in the United States. The first stage of this decision is whether or not the judge denies bail. Eight percent of the defendants in the study were denied bail. Demuth (2003) found that race and/or ethnicity had a significant effect on the decision to deny bail. The odds of black defendants being denied bail was 1.21 and the odds for Hispanic defendants was 1.23. Although statistically significant, this finding was not substantively significant. 
This is a preprint of an article whose final and definitive form has been published in the Women and Criminal Justice (c) 2009 [copyright

Taylor \& Francis]; Women and Criminal Justice is available online at: http://www.informaworld.com doi: 10.1080/08974450902791286

Other research has confirmed these findings. Demuth \& Steffensmeier (2004) found that black and Hispanic defendants were more likely to be denied bail. They found support to suggest that race/ethnicity may be more important predictors of the denial of bail than the defendant's gender. Schlesinger (2005) found that black and Hispanic defendants each were almost $25 \%$ more likely to be denied bail compared to white defendants. These differences were even more pronounced for specific types of crimes. For example, with drug crimes, black defendants were $80 \%$ and Hispanic defendants were $67 \%$ more likely to be denied bail compared to white defendants. For violent crimes, Schlesinger (2005) found that black defendants were $33 \%$ more likely to be denied bail - no significant relationship between ethnicity and denial of bail was found.

\section{Decision to Grant Financial Release}

The next stage of the pretrial release process addresses whether or not the defendant received a financial release. Albonetti (1989) found no statistically significant effects of race, sex, or age on the non-financial release decision. Maxwell (1999), too, found that there were no race effects in the decision to give a non-financial release (i.e., release on own recognizance or ROR). However, Maxwell (1999) did find that women are approximately 50\% more likely to receive a non-financial release.

Other scholars, though, have found racial/ethnic effects. When judges were given the opportunity to order a financial release, Hispanic offenders were more likely to receive a financial release than either white or black offenders - no difference was found between white and black defendants (Demuth 2003; Demuth \& Steffensmeier 2004). In the most recent published study to date, Schlesinger (2005) suggested that race and/or ethnicity did significantly affect the non-financial release decision. More specifically, black defendants had $12 \%$ less odds of receiving a ROR than white defendants. Hispanic defendants had $25 \%$ less odds of receiving a ROR than white defendants (Schlesinger 2005).

Demuth and Steffensmeier (2004) found that the interaction of gender and race/ethnicity had a role in the decision to grant non-financial release. They found that Hispanic males were $17 \%$ more likely to be granted a financial release, instead of a ROR, than white females. Therefore, it may be important to conduct fixed-effect analyses regarding the differential impact of race and/or ethnicity on the non-financial release decision for female and male defendants.

Financial Release Amount

The amount of bail (or financial release) is the next decision point in the process of granting pretrial release. Nagel (1983) found that race, sex, and age did not have a statistically significant effect on bail amount. However, changes in these decisions and overall court-processing decisions may suggest differently.

Similar to the effects found in the decision to grant non-financial releases, Hispanic offenders received higher bail amounts than white defendants - no difference existed between black and white defendants (Demuth 2003; Demuth \& Steffensmeier 2004). Schlesinger (2005) again supported this conclusion, finding that Hispanic defendants received financial releases that were $12 \%$ higher than white defendants.

Gender also has a role in pretrial release decisions. Steury \& Frank (1990) found that female defendants were significantly more likely to post bond of less than $\$ 250$ and significantly less likely to post bond of more than $\$ 1,000$ compared to male defendants. In addition, the intersection of race/ethnicity and gender also proved to be significant in the bail amount decision. Hispanic male defendants received 25\% greater bail amounts than white females (Steury \& Frank, 1990).

Pretrial Incarceration and Making Bail

Defendants who receive financial releases may not be able to pay their bail amount and, therefore, may not be released prior to trial. Black and Hispanic defendants are more likely to be held on bail than white defendants (Demuth 2003). Demuth (2003) suggested that defendants who were given financial releases but remained in detention prior to trial simply could not afford the release. Demuth and Steffensmeier (2004) found that Hispanic males were $21 \%$ more likely to be unable to post bail than white females. Therefore, again, it is important to use fixed-effect models (i.e., gender specific and/or race specific models) to address these concerns. 
This is a preprint of an article whose final and definitive form has been published in the Women and Criminal Justice (0) 2009 [copyright

Taylor \& Francis]; Women and Criminal Justice is available online at: http://www.informaworld.com doi: 10.1080/08974450902791286

Demuth (2003) found that black and Hispanic offenders were more likely to be detained prior to trial than white defendants, controlling for legally-relevant factors. Hispanic offenders had the greater odds of being detained prior to trial than any racial or ethnic group. Race and ethnicity, therefore, are significant predictors of whether or not a defendant is detained prior to trial. The intersection of race/ethnicity and gender also provides significant results. Hispanic male defendants have a $23 \%$ greater probability of being jailed prior to trial than white females (Demuth, 2003).

The proposed study will address these same decisions and outcomes but in a gender-specific analysis, comparing female defendants to male defendants. The previously discussed research often is based on a single jurisdiction. The nationwide data used by Demuth (2003) and Schlesinger (2005) excluded female defendants due to low cell numbers in racial/ethnic categories at the county level. Demuth (2003) suggested that there were too few female defendants to offer intersections between gender and race/ethnicity. The data available to Demuth (2003) were limited to only four time waves: 1990, 1992, 1994, and 1996. Schlesinger (2005) proffered that inclusion of female defendants was beyond the scope of her study. She also argued that the inclusion of female defendants would be impractical to analyze the intersection of race/ethnicity and gender. The limited information on the court processing of female defendants necessitates a nationwide, gender-specific analysis such as that afforded to the experiences of male defendants.

This current study will be an approximate, but not identical, replication of two prior studies using this dataset: Demuth (2003) and Schlesinger (2005). The main distinction between the proposed study and their studies is the inclusion of female defendants and their comparison to male defendants. The current study, therefore, examines female defendants previously excluded from major investigations of this dataset to better understand the significant predictors of decisions and outcomes at pretrial stages for female offenders

\section{METHODOLOGY}

Research Question and Hypotheses

Two questions were addressed in this study: (1) do pretrial decisions and outcomes vary across genders and (2) do predictors of pretrial decisions and outcomes vary across genders. According to previous studies (e.g., Demuth, 2003; Schlessinger, 2005; Steffensmeier, et al., 1998) the following hypotheses were tested in an attempt to answer this study's research questions:

H1: Male defendants are more likely to be denied bail than female defendants.

H2: Female defendants are more likely to be granted a non-financial release (ROR) than male defendants.

H3: Male defendants are more likely to have higher bail amounts than female defendants.

H4: Female defendants are more likely to make bail than male defendants.

H5: Male defendants are more likely to be detained prior to trial than female defendants.

H6: Legal factors will have a consistent, significant effect across gender in each of these decisions and outcomes.

\section{Study Data}

This study uses data from the State Court Processing Statistics (SCPS), 1990-2000: Felony Defendants in Large Urban Counties (Bureau of Justice Statistics 2004). The data were designed to reflect felony court filings in the 75 most populous counties in the United States. The original sampling procedure was a two-stage stratified procedure. The first stage was a stratified sample of 40 of the 75 most populous counties in the United States. The second stage was a systematic sample of felony filings within each county. Each felony filing was tracked until it reached final disposition - or, until a year elapsed whichever came first. The felony filings in May of the sampled year in these 40 large metropolitan counties were tracked (up to a year) every two years from 1990 - 2000 (i.e., 1990, 1992, 1994, 1996, 1998, and 2000). A final, overall sample included 87,437 felony filings. In this original data, there were approximately 14,243 female defendants.

The current study limited the data in two important ways. First, it was limited to data that only produced nonmissing values in each of the following variables: age, race/ethnicity, gender, and prior felony convictions. This restriction was used to reduce the potential for biased effects. The result was a sample of 10,349 females and 53,372 males. The second limitation was to reduce the male-only sample to a similar size as the female-only sample in 
This is a preprint of an article whose final and definitive form has been published in the Women and Criminal Justice (0) 2009 [copyright

Taylor \& Francis]; Women and Criminal Justice is available online at: http://www.informaworld.com doi: 10.1080/08974450902791286

order to provide an equally-sized comparison between gender-specific samples. A random sample equaling 10,349 male defendants was taken from the remaining male defendants. This sampling procedure is identified as a disproportionate stratified sample which takes "a larger than proportionate number of certain groups to assure the appearance of a sufficient number of cases for comparative purposes of a group that is small in the population." (Hagan, 2005, p. 136; see also Champion, 2006; Maxfield \& Babbie, 2008). "[I]f only a small number of people in a population exhibit some attribute or characteristic of interest, then a large sample must be drawn to produce adequate numbers of elements that exhibit the uncommon condition." (Maxfield \& Babbie, 2008, p. 229).

The dataset includes many stages of court processing from charging to sentencing decisions, including pretrial release decisions. It also includes key variables that may impact these decisions, including case factors, case processing factors, and demographic factors.

\section{Dependent Variables}

There are five dependent variables used in this study. As Demuth (2003) noted, three of these variables (Denial of Bail, Non-Financial Release, and Amount of Financial Release) are pretrial release decisions whereas the other two (Made Bail and Pretrial Incarceration) are pretrial outcomes.

\section{Decisions}

The first dependent variable ("Denial of Bail") measures whether or not the defendant was denied bail (or pretrial release). This variable is coded 1 if the defendant was denied bail and 0 if the defendant was not denied bail. The second dependent variable is "Non-Financial Release." For defendants who were granted a release from incarceration prior to trial, this dependent variable measures whether or not the defendant was granted a nonfinancial release (i.e., released on own recognizance or ROR). This variable is coded 1 if the defendant was granted a non-financial release and 0 if the defendant was not granted a non-financial release. For defendants who were granted a financial release, the third variable ("Amount of Financial Release") measures the amount of financial release ordered. The original coding of this variable was in dollars; however, due to the skewed nature of this variable, the current study used the natural log of the amount of financial release.

\section{Outcomes}

The first of these dependent variables ("Made Bail") measures the ability of the defendant to pay the financial release. It is coded 1 if the defendant was offered a financial release and was released, indicating that the defendant made bail, or 0 if the defendant was offered a financial release and was not released, indicating that the defendant did not make bail. The second dependent variable ("Pretrial Incarceration") measures whether or not the defendant was released from incarceration prior to trial. It is coded 1 if the defendant was in jail prior to trial and 0 if the defendant was released from jail prior to trial.

\section{Independent Variables}

Legal Variables

Several independent variables are used for this study. Prior criminal record, type of current charge, number of current charges, and the defendant's status in the criminal justice system were proxies for legal variables. Schlesinger (2005) identified several proxies for prior criminal record which were included in the current analysis: the number of prior prison terms, the number of prior jail terms, the number of prior felony convictions ${ }^{1}$, the incidence of prior violent convictions, and the incidence of prior failure to appear convictions. The type of charge at arrest is defined as a dummy variable with five categories - violent, property, drug, public order, and other. The drug charge category is the reference category. The number of charges at arrest is a count variable. Criminal justice status refers to whether or not the defendant was active in the system at the time of the arrest. It is coded 1 if the defendant was active in the criminal justice system at the time of the current offense, or 0 if the defendant was not active in the criminal justice system at the time of the current offense.

\section{Extralegal Variables}

Based on past findings of unwarranted disparity in criminal court processing, the current study also includes extralegal variables. Since the main hypothesis is that women are treated differently than men in pretrial release decisions, the study used gender specific models for all of the analyses. The study also includes race and/or ethnicity. This variable was recoded as a dummy variable of four categories - white, black, Hispanic, and other.

\footnotetext{
${ }^{1}$ Each of these three variables - prior prison term, prior jail term, and prior felony convictions - are count variables
} with a range from 1 to 10 where 10 is defined as " 10 or more." 
This is a preprint of an article whose final and definitive form has been published in the Women and Criminal Justice () 2009 [copyright

Taylor \& Francis]; Women and Criminal Justice is available online at: http://www.informaworld.com doi: 10.1080/08974450902791286

"White" was the reference category. Age of the defendant was measured in years. A final extralegal variable is the type of defense attorney which was coded as a dummy variable - private attorney, public attorney, and other. The "other" category was used as the reference category.

Analytical Procedures

The current study proposes to replicate the studies conducted by Demuth (2003) and Schlesinger (2005) in order to address the reliance on extralegal factors (i.e., race/ethnicity and age) in pretrial release decisions and outcomes for female defendants compared to male defendants. The analysis includes five gender-specific models with crime type as an independent variable to test for differences in significant predictors across gender. Although prior research (see Demuth, 2003; Schlesinger 2005) addressed these differences with male defendants between counties, the current study is limited in that respect. Due to the problem of "zero-cells" in racial groups for female defendants at the county-level, analyses by county were not an option for this study. Although the current study loses important geographical effects, it gains knowledge about the effect of the gender of the defendant in pretrial release decisions and outcomes that would otherwise remain purely anecdotal.

This study uses a logistic regression analysis for four of the dependent variables (denial of bail, financial release, pretrial incarceration, and making bail) because they were measured at a dichotomous level (Aldrich \& Nelson 1984; Menard 2002). Ordinary Least Squares (OLS) regression was used for the remaining dependent variable (amount of financial release). A final set of analyses were run to compare unstandardized coefficients between independent samples (Paternoster, Brame, Mazerolle, \& Piquero 1998).

\section{FINDINGS}

\section{Descriptive Analyses}

The current study included 20,698 cases - half of which were male defendants and half of which were female defendants - over the six cohorts included in this dataset. Table 1 summarizes the descriptive statistics of the entire sample and gender-specific samples. Only 5.6 percent were denied bail (7.3\% for males; $4.0 \%$ for females), whereas 34.4 percent were given a non-financial release ( $28.7 \%$ for males; $40.1 \%$ for females). Of those defendants who were given a financial release, the average of the logged bail amount is 8.804 which translated into an approximate $\$ 6,600$ average financial release amount (approximately $\$ 7,900$ for males; approximately $\$ 5,500$ for females).

\section{INSERT TABLE 1 HERE}

Of those who were given a financial release option, 51.8 percent were able to make bail (45.3\% for males; $59.3 \%$ for females). In other words, over half of those defendants who were given a financial release were able to pay the bail that was set and be released. Approximately one-third of all defendants were detained prior to trial (39.5\% of males; $24.9 \%$ of females).

\section{Multivariate Analyses}

\section{Decisions}

Deny Bail. The current study ran separate gender-specific analyses for each of the five dependent variables. Results for all of the multivariate analyses for the pretrial release decisions (deny bail, non-financial release, and logged bail amount) are summarized in Table 2. In the logistic analysis of deny bail, for male defendants, the statistically significant predictors were: type of charge (violent, property, and public order), prior felony convictions, criminal justice status, and the type of defense attorney (public attorney). The model resulted in an $11.9 \%$ reduction in error (Naglekerke $R^{2}=0.119$ ). Male defendants who were charged with a public order offense were over $31 \frac{1}{2}$ times more likely to be denied bail than those defendants who were charged with a drug offense. Criminal justice status also produced substantively significant results. Male defendants who were already in the criminal justice system were over four times more likely to be denied bail than male defendants not already in the system.

For female defendants, the statistically significant predictors were: type of charge (property and public order), prior felony convictions, criminal justice status, race/ethnicity (other race), and type of defense attorney (public attorney). The model resulted in a $15.7 \%$ reduction in error (Naglekerke $\mathrm{R}^{2}=0.157$ ). Unlike male defendants, female defendants who were charged with a property offense were less likely to be denied bail than female defendants who were charged with a drug offense. Female defendants who were charged with a public order offense were 
This is a preprint of an article whose final and definitive form has been published in the Women and Criminal Justice (0) 2009 [copyright Taylor \& Francis]; Women and Criminal Justice is available online at: http://www.informaworld.com doi: 10.1080/08974450902791286

approximately 2.3 times more likely to be denied bail than those charged with a drug offense. Additionally, female defendants who were already in the criminal justice system were over six times more likely to be denied bail than those who were not in the system. While race/ethnicity was not a predictor for male defendants, it was for female defendants. Females of other races were over $5 \frac{1}{2} 2$ times less likely to be denied bail than white female defendants.

Non-Financial Release. Similar results were found for whether or not a non-financial release was ordered. For the male-only model, several variables were found to be statistically significant: type of charge (violent, property, and public order), prior record (prior jail terms, prior felony convictions, and prior FTA conviction), criminal justice status, ethnicity (i.e., Hispanic), and type of attorney (private and public). More specifically, male defendants who were charged with a violent offense or a public order offense were approximately three times less likely to obtain a non-financial release than those charged with a drug offense. Hispanic male defendants were over two times less likely to receive a non-financial release than white offenders. The only other substantive effect is the type of attorney. Male defendants with a public defendant were over $2 \frac{1}{2}$ times less likely to receive a non-financial release than those with other types of defense systems. Male defendants with a private defense attorney were over $31 / 2$ times less likely to receive a non-financial release than those with other types of defense systems. The model resulted in a $9.3 \%$ reduction in error (Naglekerke $\left.\mathrm{R}^{2}=0.093\right)$.

For the female-only model, only one charge type variable (violent) was found to be significantly related to the likelihood of receiving a non-financial release albeit with a modest effect (odds ratio $=0.710$ ). Female defendants who were charged with a violent offense were approximately two times less likely to receive a non-financial release than those charged with a drug offense. Other variables that were found to be statistically significant: prior record (prior prison terms, prior jail terms, prior felony convictions, and prior FTA convictions), criminal justice status, and type of attorney (private and public). For female defendants, race/ethnicity is no longer a significant effect. The model resulted in a $11.4 \%$ reduction in error $\left(\right.$ Naglekerke $\left.R^{2}=0.114\right)$.

Amount of Bail. The final pretrial release decision is the amount of bail. Due to the skewed nature of the distribution $^{2}$, the logged value of this variable was taken to reflect a distribution that mirrors normality. For the male-only sample, the legal variables continued to have a significant effect on the amount of bail assigned: type of charge (violent, property, and other), prior record (prior prison terms, prior jail terms, prior felony convictions, and prior FTA conviction), and number of current charges. More specifically, male defendants who were charged with a violent offense received a higher bail amount than those charged with a drug offense, whereas those charged with a property or other offense received a lower bail amount than if they were charged with a drug offense. A surprising finding was that male defendants with more prior felony convictions received a lower bail amount. The same surprising result was found for whether or not the defendant had a prior FTA conviction.

The extralegal variables of ethnicity and type of defense attorney (private and public) also played a role in the maleonly model. Hispanic male defendants received a higher bail amount than White male defendants. In fact, the standardized effects indicated that ethnicity was just as important of a variable as whether the defendant was charged with a violent offense or the number of prior prison terms (ethnicity, $\beta=0.130$; violent charge, $\beta=0.133$; prior prison terms, $\beta=0.138$ ). The next relatively important factor in the prediction of logged bail amount was whether the defendant was represented by a public defense attorney $(\beta=0.114)$. The model explained $9.1 \%$ of the variance (Adjusted $\mathrm{R}^{2}=0.091$ ).

Much like the male-only model, legal factors were statistically significant for female defendants: type of charge (violent and property), prior record (prior jail terms and prior FTA conviction), number of charges, and criminal justice status. Unlike male defendants, though, the female-only model indicated a significant effect of both ethnicity (Hispanic) and race (Black) on the logged amount of bail. However, these effects are in the opposite direction of each other. Hispanic female defendants have higher bail amounts, while black female defendants have lower bail amounts than white female defendants. Finally, the most important predictor of all of the statistically significant variables was whether or not the female defendant had a public attorney $(\beta=0.131)$. The model explained $7.7 \%$ of the variance (Adjusted $R^{2}=0.077$ ).

\section{INSERT TABLE 2 HERE}

\footnotetext{
${ }^{2}$ Most defendants receiving a financial release incur a fairly minimal amount of bail whereas the minority of defendants incur a much larger amount.
} 
This is a preprint of an article whose final and definitive form has been published in the Women and Criminal Justice (C) 2009 [copyright

Taylor \& Francis]; Women and Criminal Justice is available online at: http://www.informaworld.com doi: 10.1080/089744550902791286

\section{Outcomes}

Made Bail. The results of the multivariate analyses on made bail and pretrial incarceration are summarized in Table 3. As with the other dependent variables, legal variables were statistically significant for the male-only model: type of charge (violent, property, and other), prior record (prior prison terms, prior jail terms, prior felony convictions, and prior FTA conviction) and criminal justice status. Ethnicity and type of defense attorney (private and public) were found to be significant predictors of whether or not the defendant made bail. Hispanic male defendants are almost three times less likely to make bail than white male defendants. Defendants with public defense attorneys were over three times as likely not to make bail, whereas defendants with private defense attorneys were over twice as likely to make bail. The model resulted in a $23 \%$ reduction in error (Naglekerke $\mathrm{R}^{2}=0.230$ ).

The female-only model produced similar results. Legal variables had a statistically significant impact on whether or not the defendant made bail: type of charge (violent, property, public order, and other), prior record (prior prison terms, prior jail terms, prior violent conviction, and prior FTA conviction), and criminal justice status. It appears also that for female defendants (unlike male defendants) being charged with a drug offense carries with it the lowest likelihood of making bail. Interestingly, compared to the male-only model, the existence of a prior violent conviction for a female defendant is significant for the outcome of making bail. In addition, prior violent conviction has its largest impact, unlike all of the decision analyses for both male and female defendants, among all of the prior record variables (odds $=1.482$ ) - albeit moderate nonetheless. Again, ethnicity and type of defense attorney were statistically significant in the female-only model. Hispanic female offenders were over $2 \frac{1}{2}$ times less likely to make bail than white female offenders. Female defendants with public attorneys were over twice as likely not to make bail, whereas female defendants with a private defense attorney were over $2 \frac{1}{2}$ times more likely to make bail than other defense systems. The model resulted in a $24.3 \%$ reduction in error $\left(\right.$ Naglekerke $\left.\mathrm{R}^{2}=0.243\right)$.

Pretrial Incarceration. The final dependent variable was whether or not the defendant was detained prior to trial. In the male-only sample, legal variables once again proved to be statistically significant: type of charge (violent, property, and public order), prior record (prior prison terms and prior jail terms), and criminal justice status. Extralegal variables also proved to be statistically significant. Hispanic male defendants were more likely to be detained prior to trial than white defendants. Male defendants who were assigned a public defense attorney were over twice as likely to be detained as those with alternative defense systems. The model resulted in an $18.2 \%$ reduction in error (Nagelkerke $\left.\mathrm{R}^{2}=0.182\right)$.

For the female-only sample, different results were found. Although some legal variables were found to be significantly related to whether or not female defendants were detained, several of these variables were in the opposite direction compared to the male-only sample. For example, a female defendant who was charged with a property offense was less likely to be detained than a female defendant who was charged with a drug offense. Contrarily, a male defendant charged with a property offense was more likely to be detained than a male defendant charged with a drug offense. Additionally, unlike male defendants, female defendants charged with a violent offense had no different odds of being detained than those charged with a drug offense. Other legal variables for female defendants that indicated a statistically significant relationship to the likelihood of pretrial incarceration were prior record (prior prison terms, prior jail terms, prior felony conviction, and prior violent conviction) and criminal justice status. Similar to male defendants, Hispanic female defendants were more likely to be detained than white female defendants (odds = 1.283). Additionally, female defendants with a public defense attorney were over twice as more likely to be detained than female defendants with alternative defense types. The pretrial incarceration model resulted in a $21 \%$ reduction in error (Nagelkerke $\left.\mathrm{R}^{2}=0.208\right)$.

\section{INSERT TABLE 3 ABOUT HERE}

\section{Comparison of Unstandardized Coefficients Between Independent Samples}

The final analyses compared statistically significant unstandardized coefficients between the independent samples (i.e., male defendants and female defendants). This type of analysis computes a standardized $\mathrm{Z}$ score to address whether one statistically significant variable has a stronger impact on the dependent variable in one sample compared to the other sample (see Paternoster et al., 1998). Given independent samples, the researcher can mete out interactive effects given fixed, independent models. These analyses are summarized in Table 4 (pretrial release decisions) and Table 5 (pretrial release outcomes). 
This is a preprint of an article whose final and definitive form has been published in the Women and Criminal Justice () 2009 [copyright

Taylor \& Francis]; Women and Criminal Justice is available online at: http://www.informaworld.com doi: 10.1080/08974450902791286

\section{Decisions}

Deny Bail. For the analysis on the denial of bail, the only significant difference between male and female defendants was being charged with a property crime. The effect of property charge has a larger impact for males than females $(Z=3.948, \mathrm{p}<.05)$. In other words, male defendants experience a greater likelihood of being denied bail if charged with a property offense than female defendants. In fact, female defendants are less likely to be denied bail if charged with a property offense than if charged with a drug offense.

Non-financial release. Two variables had significantly different impacts for male and female defendants: violent current charge and number of prior jail terms. Being charged with a violent offense had a larger impact on receiving a non-financial release for male defendants as compared to female defendants $(Z=3.128, p<.05)$. The opposite is true for the existence of prior jail terms. Evidence of prior jail terms had a more substantive impact on the likelihood of receiving a non-financial release for female defendants as compared to male defendants $(\mathrm{Z}=2.445, \mathrm{p}<.05)$.

Bail Amount. The $\mathrm{Z}$ score was only statistically significant on one independent variable, whether or not the defendant was charged with a violent offense $(Z=2.942, p<.05)$. This result suggests that the impact of whether or not a defendant is charged with a violent offense is heightened for male defendants compared to female defendants. In other words, male defendants received higher bail amounts due to a violent charge than female defendants.

\section{INSERT TABLE 4 ABOUT HERE}

\section{Outcomes}

Made Bail. There were greater differences in regression coefficients between the two independent samples for whether or not the defendant made bail. The impact of type of charge (violent charge $(Z=-5.357, p<.05)$ and property charge $(Z=-5.794, p<.05)$ ) was significantly different for male and female defendants. Having a violent charge and/or a property charge compared to drug charges resulted in a significantly greater likelihood of not making bail for male compared to female defendants. Additionally, being Hispanic had a greater negative impact for male defendants than for female defendants $(Z=-2.480, p<.05)$.

Pretrial Incarceration. Finally, there were several regression coefficient comparisons on whether or not the defendant was detained prior to trial that resulted in statistically significant $\mathrm{Z}$ score values. First, a property charge had a more significant impact on whether or not the defendant was detained for male than for female defendants $(Z$ $=6.289, \mathrm{p}<.05)$. In fact, male defendants who were charged with a property offense were more likely to be detained whereas female defendants were less likely to be detained. A somewhat surprising result was that the effect of prior jail terms on pretrial incarceration had more of an impact on female defendants than for male defendants $(Z=-2.325, \mathrm{p}<.05)$. In other words, female defendants who experienced a higher number of prior jail terms were more impacted than male defendants. Being Hispanic $(Z=2.751, p<.05)$ and having a public defense attorney $(Z=5.655, \mathrm{p}<.05)$ had a larger impact on whether or not the defendant was detained for male defendants than for female defendants.

\section{INSERT TABLE 5 ABOUT HERE}

\section{DISCUSSION}

Based on the descriptive statistics, hypotheses 1-5 were all supported. A greater percentage of male defendants compared to female defendants were denied bail and were detained prior to trial. Male defendants had a higher average bail amount than female defendants. A greater percentage of female defendants compared to male defendants received a non-financial release (ROR) and made bail.

Support for hypothesis 6 regarding the effects of legal factors is a little more complex. While legal factors had a significant effect on both pretrial decisions and outcomes, extralegal factors did as well. Type of charge was a significant predictor for every decision and outcome across both genders. Some form of prior contact with the criminal justice system, such as prior jail terms, prior prison terms, prior violent charge, or prior FTA, was a significant predictor for every decision and outcome across both genders. For criminal justice status, this legal variable was significant for all of the dependent variables across both genders, except for the amount of bail for male defendants. In the $\mathrm{Z}$ score comparison, only legal variables had a differential impact based on gender across all decisions and outcomes. 
This is a preprint of an article whose final and definitive form has been published in the Women and Criminal Justice (0) 2009 [copyright

Taylor \& Francis]; Women and Criminal Justice is available online at: http://www.informaworld.com doi: 10.1080/08974450902791286

At the same time, extralegal variables, such as race, ethnicity, and type of defense attorney were also significant predictors of pretrial decisions and outcomes. Race and/or ethnicity were a significant predictor for every decision and outcome with the exception of the decision to deny bail for male defendants and granting a non-financial release for female defendants. The type of defense attorney, especially having a public defender, was a significant predictor in all of the analyses. And, in the $\mathrm{Z}$ score comparison, ethnicity had a greater impact for male defendants in the made bail and pretrial detention outcomes. Thus, we can conclude that hypothesis 6 was supported in this analysis as legal factors were significant predictors of decisions and outcomes across both genders, but extralegal factors continue to play an important role in pretrial processing for both male and female defendants

\section{Differential Impact of Factors Across Genders}

The $\mathrm{Z}$ score analysis provided a direct comparison of the impact of variables on pretrial decisions and outcomes between male and female defendants. For some dependent variables, only one independent variable proved to have a differential impact. In the decisions to deny bail and set a bail amount, the only significant difference between the genders involved the type of charge. In both instances, the type of charge had a greater impact on decisions involving male rather than female defendants. In fact, the type of charge had a greater impact only on male defendants across all pretrial decisions and outcomes. A similar finding occurred with both ethnicity and type of defense attorney. These two extralegal variables were significant predictors for both male and female defendants in terms of the outcomes of making bail and pretrial incarceration, but being Hispanic and having a public defender proved to have a greater impact on male defendants.

As it stands with the current analysis, only the legal variable of prior jail terms had a greater impact on female defendants in receiving a non-financial release and on the outcome of pretrial incarceration. Having previously served time in jail differentially decreased the likelihood of receiving a non-financial release and increased the likelihood of being incarcerated prior to trial compared to male defendants.

Why would this one variable have such an impact on decisions and outcomes affecting female defendants, but not male defendants? The explanation may lie in hypotheses regarding the discriminatory treatment of both men and women during criminal justice processing. Belknap (2000) discusses three hypotheses: equal treatment, chivalry or paternalism, and evil woman. Under the equal treatment hypothesis, male and female defendants would be handled identically. The same significant predictors would exist for both genders in all pretrial decisions and outcomes. There certainly is gender convergence in the types of offenses for which men and women are arrested. And, there are more similarities than differences in significant predictors for pretrial decisions and outcomes across the genders. Under the chivalry or paternalism hypothesis, male defendants are actually the ones facing discrimination in that women for either chivalrous or paternalistic reasons are treated more leniently. Across all pretrial decisions and outcomes, male defendants were negatively impacted by the type of offense they were charged with to a greater extent than female defendants. Thus, females are possibly being treated more leniently than male defendants. Under the evil woman hypothesis, female defendants are discriminated against because they have violated the societal model of what a woman is. In our findings, women were negatively impacted by prior jail terms to a greater extent than male defendants in terms of making bail and pretrial incarceration. Therefore, they were possibly being treated more harshly than male defendants. It may be, in pretrial processing, that, initially, female defendants are given the benefit of the doubt when charged with a violent crime because that does not fit the stereotype of a woman (chivalry/paternalism). But, when faced with evidence that a woman truly is a criminal (prior jail terms), female defendants are treated more harshly than males because they have violated the female stereotype (evil woman).

\section{Limitations}

There are a few limitations in the current study. As with most secondary data, the current study cannot control for all theoretically relevant variables. Although data were present on failure to appear convictions, a more precise measure on risk of flight would also be important to include in a study of pretrial release decisions. One of the more important factors driving bail decisions is the likelihood of the defendant's return. Therefore, family and community ties or economic capabilities could influence a judicial decision on releasing a defendant. Another potentially important variable highlighting differences in effects between male and female defendants are familial concerns that judges may have regarding the release of female defendants. It would be relevant to control for marital status and the existence of dependents under the defendant's care. It would also be relevant to include data 
This is a preprint of an article whose final and definitive form has been published in the Women and Criminal Justice $\odot 2009$ [copyright

Taylor \& Francis]; Women and Criminal Justice is available online at: http://www.informaworld.com doi: 10.1080/08974450902791286

about overcrowding in the local detention center or jail. Judicial decisions can originate from practical implications such as overcrowding (see Steffensmeier et al., 1998). Finally, since the American prosecutor executes a great amount of discretion, it would also be relevant to include data regarding the quality of bail requests by the prosecutor.

Finally, the method of randomly selecting male defendants forces the current study to eliminate potentially important cases which may alter the study's findings. The sample used in this study, however, is similar in demographic makeup to the sample used in other studies using this dataset (see Demuth \& Steffensmeier, 2004; Schlessinger, 2005). Even though the demographic makeup is similar, there could be the potential of selection bias. However, this bias is remote and should not impede the validity of the findings.

Areas of Future Research

It is our hope that future research will continue to compare the processing of male and female offenders at criminal justice system decision points. With the dearth of research regarding the processing of female defendants but increasing numbers of women offenders, it is imperative that more research is undertaken to examine their experiences in the criminal justice system. Along these same lines, one variable that is rarely examined but may have differential impacts on the processing of female defendants is the amount of space for female defendants/offenders in local jails. The issue of jail space may impact both pretrial and sentencing decisions for female defendants. Finally, we offered a rudimentary discussion of the potential explanations for differential treatment of male and female defendants using the three hypotheses of sex discrimination in the criminal justice system. More extensive work and testing of these hypotheses may assist in uncovering unfounded differential treatment of both male and female defendants in the criminal justice system.

\section{REFERENCES}

Albonetti, C. A. (1987). Prosecutorial discretion: The effects of uncertainty. Law and Society Review, 21, $291-313$.

Albonetti, C. A. (1989). Bail and judicial discretion in the District of Columbia. Sociology and Social Research, $74,40-47$.

Aldrich, J., \& Nelson, F. (1984). Linear Probability, Logit, and Probit Models. Beverly Hills, CA: Sage.

Belknap, R.A. (2000). One woman's life viewed through the interpretive lens of Gilligan's theory. Violence Against Women, 6, 586-605

Blumstein, A., Cohen, J., Martin, S. E., \& Tonry, M. H. (Eds.). (1983). Research on Sentencing: The Search for Reform (Vols. 1-2). Washington, D.C.: National Academy Press.

Brereton, D., \& Casper, J. (1981-1982). Does it pay to plead guilty? Differential sentencing and the functioning of the criminal courts. Law \& Society Review, 16, 45-70.

Britt, C. L. (2000). Social context and racial disparities in punishment decisions. Justice Quarterly, 17, 707-732.

Bureau of Justice Statistics. (2004). State Court Processing Statistics, 1990-2000: Felony Defendants In Large Urban Counties [Computer file]. Conducted by Pretrial Services Resource Center [producer], 2004. ICPSR ed. Ann Arbor, MI: Inter-university Consortium for Political and Social Research [distributor].

Champion, D. J. (2006). Research Methods for Criminal Justice and Criminology ( ${ }^{\text {rd }}$ Ed.). Upper Saddle River, NJ: Pearson.

Chiricos, T. G., \& Bales, W. D. (1991). Unemployment and punishment: An empirical assessment. Criminology, 29, 701-724.

Cox, S. (1976). Prosecutorial discretion: An overview. American Criminal Law Review, 3, 383-434. 
This is a preprint of an article whose final and definitive form has been published in the Women and Criminal Justice $\odot 2009$ [copyright

Taylor \& Francis]; Women and Criminal Justice is available online at: http://www.informaworld.com doi: 10.1080/08974450902791286

Demuth, S. (2003). Racial and ethnic differences in pretrial release decisions and outcomes: A comparison of Hispanic, black, and white felony arrestees. Criminology, 41, 873-908.

Demuth, S., \& Steffensmeier, D. (2004). The impact of gender and race-ethnicity in the pretrial release process. Social Problems, 51, 222-242.

FBI (2006). Crime in the United States 2006: Uniform Crime Reports. Washington, D.C.: United States Department of Justice.

Goldkamp, J. S., \& Gottfredson, M. R. (1979). Bail decision making and pretrial detention. Law and Human Behavior, 3, 227-249.

Gottfredson, M. R., \& Gottfredson, D. M. (1988). Decision Making in Criminal Justice, $2^{\text {nd }}$ Ed.). New York: Plenum.

Hagan, F. E. (2005). Essentials of Research Methods in Criminal Justice and Criminology. Boston: Pearson.

Hagan, J. (1974). Extra-legal attributes and criminal sentencing: A methodological critique. Law and Society Review, 8, 357-83.

Johnson, B. (2005). "Contextual disparities in guidelines departures. Criminology, 43, 761-797.

Maxfield, M. G., \& Babbie, E. (2008). Research Methods for Criminal Justice and Criminology (5 ${ }^{\text {th }}$ Ed.). Thomson.

Maxwell, S. R. (1999). Examining the congruence between predictors of ROR and failures to appear. Journal of Criminal Justice, 27, 127-141

Maxwell, C. D., Robinson, A. L., \& Post, L. A. (2003). The impact of race on the adjudication of sexual assault and other violent crimes. Journal of Criminal Justice, 31, 523-538.

Menard, S. (2002). Applied Logistic Regression Analysis. Thousand Oaks, CA: Sage.

Nagel, I. (1983). The legal/extra-legal controversy: Judicial decisions in pretrial release. Law \& Society Review, $17,481-515$.

Packer, H. (1968). The Limits of the Criminal Sanction. Stanford, CA: Stanford University Press.

Paternoster, R., Brame, R., Mazerolle, P., \& Piquero, A. (1998). Using the correct statistical test for the equality of regression coefficients. Criminology, 36, 859-866.

Sabol, W.J., Minton, T.D., \& Harrison, P.A. (2007). Prison and jail inmates at midyear 2006.Bureau of Justice Statistics Bulletin, June 2007.

Schlesinger, T. (2005). Racial and ethnic disparity in pretrial criminal processing. Justice Quarterly, 22, 170-192.

Spohn, C. (2002). How Do Judges Decide? The Quest for Fairness and Justice in Sentencing. Thousand Oaks, CA: Pine Forge Press.

Spohn, C., \& Cederblom, J. (1991). Race and disparities in sentencing: A test of the liberation hypothesis. Justice Quarterly, 8, 305-327.

Spohn, C., Gruhl, J., \& Welch, S. (1981-1982). The effect of race on sentencing: A re-examination of an unsettled question. Law \& Society Review, 16, 71-88. 
This is a preprint of an article whose final and definitive form has been published in the Women and Criminal Justice (C) 2009 [copyright

Taylor \& Francis]; Women and Criminal Justice is available online at: http://www.informaworld.com doi: 10.1080/08974450902791286

Steffensmeier, D. (1980). Assessing the impact of the women's movement on sex-based differences in the handling of adult criminal defendants. Crime and Delinquency, 23, 344-356.

Steffensmeier, D., Ulmer, J., \& Kramer, J. (1998). The interaction of race, gender, and age, in criminal sentencing: The punishment cost of being young, black, and male. Criminology, 36, 763-797

Steury, E. H., \& Frank, N. (1990). Gender bias and pretrial release: More pieces of the puzzle. Journal of Criminal Justice, 18, 417-432.

Turner, K. B., Secret, P. E., \& Johnson, J. B. (2003). Race as a factor in the judicial decision of bail amount in a midwestern jurisdiction. Journal of Ethnicity in Criminal Justice, 1, nos. 3/4, pp. 21-9.

Ulmer, J. T. (1997). Social Worlds of Sentencing: Court Communities Under Sentencing Guidelines. Albany, NY: State University of New York Press.

Ulmer, J. T., \& Kramer, J. H. (1996). Court communities under sentencing guidelines: Dilemmas of formal rationality and sentencing disparity. Criminology, 34, 383-407.

Walker, S. (1993). Taming the System: The Control of Discretion in Criminal Justice, 1950-1990. New York: Oxford University Press.

Walker, S., Spohn, C., \& DeLone, M. (2003). The Color of Justice: Race Ethnicity and Crime in America (2 ${ }^{\text {nd }}$ Ed.). Belmont, CA: Wadsworth. 
Table 1. Frequencies

\begin{tabular}{|c|c|c|c|c|c|c|c|c|c|c|}
\hline \multirow{3}{*}{ Denendent Variables } & & \multicolumn{3}{|c|}{ Total } & \multicolumn{3}{|c|}{ Male } & \multicolumn{3}{|c|}{ Female } \\
\hline & & $\mathbf{N}$ & $\%$ & Mean & $\mathbf{N}$ & $\%$ & Mean & $\mathbf{N}$ & $\%$ & Mean \\
\hline & & & & & & & & & & \\
\hline \multicolumn{11}{|l|}{ Pretrial Release Decisions ${ }^{+}$} \\
\hline \multirow[t]{2}{*}{ Deny Bail } & Yes & 1,167 & $5.6 \%$ & & 754 & $7.3 \%$ & & 413 & $4.0 \%$ & \\
\hline & No & 18,497 & 89.4 & & 9,072 & 87.7 & & 9,425 & 91.1 & \\
\hline \multirow[t]{2}{*}{ Non-Financial Release } & Yes & 7,116 & 34.4 & & 2,969 & 28.7 & & 4,147 & 40.1 & \\
\hline & No & 12,718 & 61.4 & & 6,947 & 67.1 & & 5,771 & 55.8 & \\
\hline Logged Bail Amount & & & & 8.804 & & & 8.969 & & & 8.612 \\
\hline \multicolumn{11}{|l|}{ Pretrial Release Outcomes } \\
\hline \multirow[t]{2}{*}{ Made Bail } & Yes & 5,426 & 51.8 & & 2,546 & 45.3 & & 2,880 & 59.3 & \\
\hline & No & 5,055 & 48.2 & & 3,076 & 54.7 & & 1,979 & 40.7 & \\
\hline \multirow[t]{2}{*}{ Pretrial Incarceration } & Detained & 6,392 & 32.2 & & 3,920 & 39.5 & & 2,472 & 24.9 & \\
\hline & Released & 13,442 & 67.8 & & 5,996 & 60.5 & & 7,446 & 75.1 & \\
\hline \multirow{2}{*}{\multicolumn{11}{|c|}{$\frac{\text { Independent Variables }}{\text { Legal Variables }}$}} \\
\hline & & & & & & & & & & \\
\hline \multirow[t]{5}{*}{ Arrest Charge Type } & Violent & 4,744 & 22.9 & & 2,674 & 25.8 & & 2,070 & 20.0 & \\
\hline & Property & 7,024 & 33.9 & & 3,176 & 30.7 & & 3,848 & 37.2 & \\
\hline & Drug & 7,484 & 36.2 & & 3,602 & 34.8 & & 3,882 & 37.5 & \\
\hline & Public Order & 610 & 2.9 & & 272 & 2.6 & & 338 & 3.3 & \\
\hline & Other & 836 & 4.0 & & 625 & 6.0 & & 211 & 2.0 & \\
\hline Prior Prison Terms & & & & 0.32 & & & 0.44 & & & 0.20 \\
\hline Prior Jail Terms & & & & 1.16 & & & 1.31 & & & 1.01 \\
\hline Prior Felony Convictions & & & & 0.86 & & & 1.09 & & & 0.63 \\
\hline \multirow[t]{2}{*}{ Prior Violent Convictions } & Yes & 1,566 & 7.6 & & 1,152 & 11.1 & & 414 & 4.0 & \\
\hline & No & 11,130 & 53.8 & & 5,799 & 56.0 & & 5,331 & 51.5 & \\
\hline \multirow[t]{2}{*}{ Prior FTA } & Yes & 5,903 & 28.5 & & 3,279 & 31.7 & & 2,624 & 25.4 & \\
\hline & No & 6,230 & 30.1 & & 3,326 & 32.1 & & 2,904 & 28.1 & \\
\hline Number of Charges & & & & 2.16 & & & 2.23 & & & 2.08 \\
\hline \multirow[t]{2}{*}{ Criminal Justice Status } & Active & 6,234 & 30.1 & & 3,587 & 34.7 & & 2,647 & 25.6 & \\
\hline & Not Active & 12,279 & 59.3 & & 5,528 & 53.4 & & 6,751 & 65.2 & \\
\hline
\end{tabular}


This is a preprint of an article whose final and definitive form has been published in the Women and Criminal Justice ( 2009 [copyright Taylor \& Francis]; Women and Criminal Justice is available online at: http://www.informaworld.com doi: 10.1080/08974450902791286

Table 1. Frequencies (cont.)

Extralegal Variables

Race/ethnicity

Age

Type of Defense Attorney

$\begin{array}{lcc}\text { Private } & 2,322 & 11.2 \\ \text { Public } & 9,625 & 46.5 \\ \text { Other } & 92 & 9.2\end{array}$

30.21

$\begin{array}{cc}4,651 & 44.9 \\ 2,700 & 26.1 \\ 2,751 & 26.6 \\ 247 & 2.4 \\ & \\ & \\ & \\ & \\ 1,096 & 10.6 \\ 4,781 & 46.2 \\ 31 & 0.3\end{array}$

$4,943 \quad 47.8$

$3,398 \quad 32.8$

$1,775 \quad 17.2$

$233 \quad 2.3$

29.45

30.97 
This is a preprint of an article whose final and definitive form has been published in the Women and Criminal Justice @ 2009 [copyright Taylor \& Francis]; Women and Criminal Justice is available online at: http://www.informaworld.com doi: 10.1080/08974450902791286

Table 2. Multivariate Analyses for Pretrial Release Decisions

\begin{tabular}{|c|c|c|c|c|c|c|c|c|c|c|c|c|}
\hline \multirow[b]{4}{*}{ Violent Charge } & \multicolumn{4}{|c|}{ Deny Bail $^{+}$} & \multicolumn{4}{|c|}{ Non-Financial Release $^{+}$} & \multicolumn{4}{|c|}{ Logged Bail Amount $^{\#}$} \\
\hline & \multicolumn{2}{|c|}{ Male } & \multicolumn{2}{|c|}{ Female } & \multicolumn{2}{|c|}{ Male } & \multicolumn{2}{|c|}{ Female } & \multicolumn{2}{|c|}{ Male } & \multicolumn{2}{|c|}{ Female } \\
\hline & $\mathrm{b}$ & odds & $\mathrm{b}$ & odds & $\mathrm{b}$ & odds & $\mathrm{b}$ & odds & $\mathrm{b}$ & Beta & $\mathrm{b}$ & Beta \\
\hline & $0.579^{*}$ & 1.785 & 0.296 & 1.344 & $-0.792^{*}$ & 0.482 & $-0.343^{*}$ & 0.710 & $0.493^{*}$ & 0.133 & $0.170^{*}$ & 0.045 \\
\hline Property Charge & $0.379^{*}$ & 1.460 & $-0.409^{*}$ & 0.664 & $-0.184^{*}$ & 0.832 & 0.096 & 1.100 & $-0.214^{*}$ & -0.060 & $-0.205^{*}$ & -0.070 \\
\hline Public Order Charge & $1.269^{*}$ & 3.558 & $0.831^{*}$ & 2.296 & $-0.643^{*}$ & 0.526 & 0.259 & 1.295 & -0.241 & -0.022 & -0.634 & -0.036 \\
\hline Other Charge & -0.266 & 0.767 & -0.169 & 0.844 & -0.072 & 0.931 & 0.206 & 1.229 & $-0.343^{*}$ & -0.052 & -0.380 & -0.038 \\
\hline Prior Prison Term(s) & 0.031 & 1.031 & 0.055 & 1.056 & -0.070 & 0.933 & $-0.236^{*}$ & 0.790 & $0.171^{*}$ & 0.138 & 0.047 & 0.036 \\
\hline Prior Jail Term(s) & -0.033 & 0.967 & 0.018 & 1.018 & $-0.068^{*}$ & 0.934 & $-0.132^{*}$ & 0.876 & $0.029^{*}$ & 0.045 & $0.042^{*}$ & 0.081 \\
\hline $\begin{array}{l}\text { Prior Felony } \\
\text { Conviction(s) }\end{array}$ & $0.066^{*}$ & 1.068 & $0.119^{*}$ & 1.126 & $-0.107^{*}$ & 0.898 & $-0.119^{*}$ & 0.888 & $-0.051^{*}$ & -0.068 & 0.005 & 0.007 \\
\hline $\begin{array}{l}\text { Prior Violent } \\
\text { Conviction }\end{array}$ & -0.221 & 0.802 & -0.311 & 0.733 & -0.140 & 0.870 & 0.074 & 1.077 & -0.081 & -0.018 & 0.018 & 0.003 \\
\hline Prior FTA Conviction & 0.173 & 1.188 & -0.126 & 0.882 & $-0.279^{*}$ & 0.756 & $-0.239^{*}$ & 0.788 & $-0.206^{*}$ & -0.064 & $-0.253^{*}$ & -0.089 \\
\hline Number of Charges & -0.011 & 0.989 & -0.044 & 0.957 & -0.022 & 0.978 & -0.033 & 0.968 & $0.087^{*}$ & 0.086 & $0.089^{*}$ & 0.098 \\
\hline Criminal Justice Status & $-1.478^{*}$ & 0.228 & $-1.817^{*}$ & 0.163 & $0.568^{*}$ & 1.765 & $0.472^{*}$ & 1.604 & -0.086 & -0.026 & $-0.119^{*}$ & -0.042 \\
\hline Black & 0.156 & 1.169 & -0.208 & 0.812 & -0.142 & 0.868 & 0.004 & 1.004 & -0.100 & -0.031 & $-0.152^{*}$ & -0.054 \\
\hline Hispanic & -0.293 & 0.746 & -0.381 & 0.683 & $-0.215^{*}$ & 0.806 & 0.002 & 1.002 & $0.475^{*}$ & 0.130 & $0.351^{*}$ & 0.091 \\
\hline Other Race & -0.877 & 0.416 & $-1.543^{*}$ & 0.214 & -0.235 & 0.791 & 0.129 & 1.138 & 0.320 & 0.031 & -0.086 & -0.009 \\
\hline Age & -0.006 & 0.995 & -0.005 & 0.995 & 0.007 & 1.007 & 0.007 & 1.007 & -0.003 & -0.019 & 0.005 & 0.028 \\
\hline Private Attorney & 0.166 & 1.181 & 0.313 & 1.368 & $-0.932^{*}$ & 0.394 & $-0.919^{*}$ & 0.399 & $0.441^{*}$ & 0.092 & $0.279^{*}$ & 0.068 \\
\hline Public Attorney & $0.316^{*}$ & 1.372 & $0.612^{*}$ & 1.844 & $-0.545^{*}$ & 0.580 & $-0.386^{*}$ & 0.680 & $0.377^{*}$ & 0.114 & $0.380^{*}$ & 0.131 \\
\hline Constant & \multicolumn{2}{|l|}{-0.509} & \multicolumn{2}{|l|}{0.376} & \multicolumn{2}{|l|}{0.079} & \multicolumn{2}{|l|}{-0.633} & \multicolumn{2}{|l|}{9.195} & \multicolumn{2}{|l|}{8.719} \\
\hline Fit Statistic & \multicolumn{2}{|c|}{$\chi^{2}=282.102^{*}$} & \multicolumn{2}{|c|}{$\chi^{2}=259.530^{*}$} & \multicolumn{2}{|c|}{$\chi^{2}=309.958^{*}$} & \multicolumn{2}{|c|}{$\chi^{2}=363.315^{*}$} & \multicolumn{2}{|c|}{$\mathrm{F}=19.109^{*}$} & \multicolumn{2}{|c|}{$\mathrm{F}=12.364^{*}$} \\
\hline Naglekerke $\mathrm{R}^{2}$ & \multicolumn{2}{|l|}{0.119} & \multicolumn{2}{|l|}{0.157} & \multicolumn{2}{|l|}{0.093} & \multicolumn{2}{|l|}{0.114} & & & & \\
\hline Adjusted $\mathrm{R}^{2}$ & & & & & & & & & 0.091 & & 0.077 & \\
\hline $\mathrm{N}$ & \multicolumn{2}{|l|}{4,856} & \multicolumn{2}{|l|}{4,195} & \multicolumn{2}{|l|}{4,899} & \multicolumn{2}{|l|}{4,234} & 3,076 & & 2,301 & \\
\hline
\end{tabular}


Table 3. Multivariate Analyses for Pretrial Release Outcomes

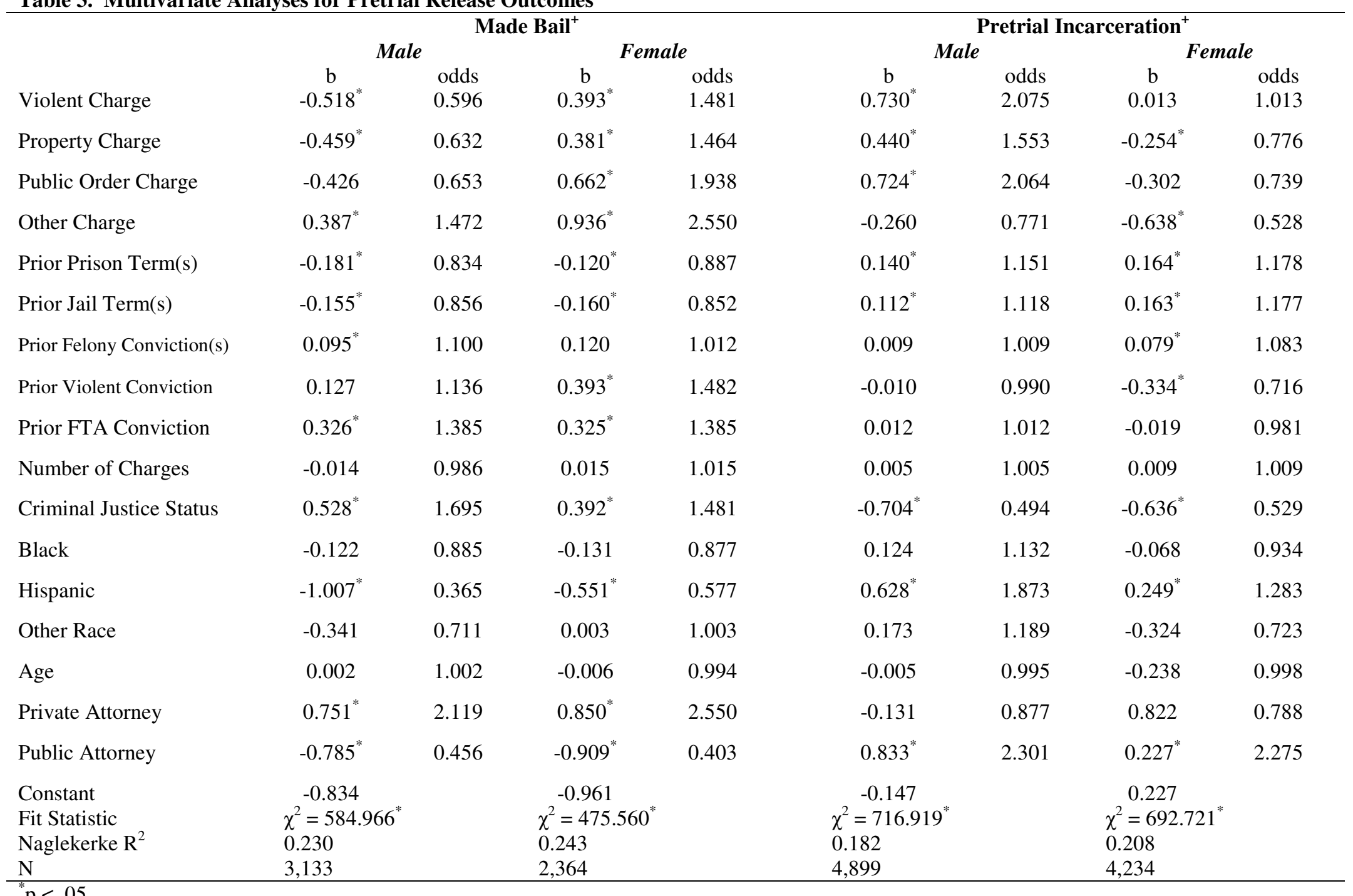

${ }^{+}$logistic regression 
Table 4. Comparison of Unstandardized Coefficients Between Independent Samples for Pretrial Decisions

\begin{tabular}{|c|c|c|c|c|c|c|c|c|c|}
\hline \multirow{2}{*}{ Violent Charge } & \multicolumn{3}{|c|}{ Deny Bail $^{+}$} & \multicolumn{3}{|c|}{ Non-Financial Release $^{+}$} & \multicolumn{3}{|c|}{ Logged Bail Amount $^{\#}$} \\
\hline & $\begin{array}{c}\text { Male } \\
\text { b } \\
0.579^{*}\end{array}$ & $\underset{\mathrm{b}}{\text { Female }}$ & Z-score & $\begin{array}{c}\text { Male } \\
\text { b } \\
-0.792^{*}\end{array}$ & $\begin{array}{c}\text { Female } \\
\text { b } \\
-0.343^{*}\end{array}$ & $\begin{array}{l}\text { Z-score } \\
-3.128^{*}\end{array}$ & $\begin{array}{c}\text { Male } \\
\text { b } \\
0.493^{*}\end{array}$ & $\begin{array}{c}\text { Female } \\
\text { b } \\
0.170^{*}\end{array}$ & $\begin{array}{c}\text { Z-score } \\
\text { 2.942 }^{*}\end{array}$ \\
\hline Property Charge & $0.379^{*}$ & $-0.409^{*}$ & $3.948^{*}$ & $-0.184^{*}$ & & & $-0.214^{*}$ & $-0.205^{*}$ & 0.095 \\
\hline Public Order Charge & $1.269^{*}$ & $0.831^{*}$ & 1.120 & $-0.643^{*}$ & & & & & \\
\hline Prior Prison Term(s) & & & & & $-0.236^{*}$ & & $0.171^{*}$ & & \\
\hline Prior Jail Term(s) & & & & $-0.068^{*}$ & $-0.132^{*}$ & $2.445^{*}$ & $0.029^{*}$ & $0.042^{*}$ & -0.735 \\
\hline Prior Felony Conviction(s) & $0.066^{*}$ & $0.119^{*}$ & -1.051 & $-0.107^{*}$ & $-0.119^{*}$ & 0.278 & $-0.051^{*}$ & & \\
\hline \multicolumn{10}{|l|}{ Prior Violent Conviction } \\
\hline Number of Charges & & & & & & & $0.087^{*}$ & $0.089^{*}$ & -0.079 \\
\hline Criminal Justice Status & $-1.478^{*}$ & $-1.817^{*}$ & 1.558 & $0.568^{*}$ & $0.472^{*}$ & 0.911 & & $-0.119^{*}$ & \\
\hline Black & & & & & & & & $-0.152^{*}$ & \\
\hline Hispanic & & & & $-0.215^{*}$ & & & $0.475^{*}$ & $0.351^{*}$ & 1.049 \\
\hline Other Race & & $-1.543^{*}$ & & & & & & & \\
\hline Private Attorney & & & & $-0.932^{*}$ & $-0.919^{*}$ & -0.072 & $0.441^{*}$ & $0.279^{*}$ & 1.206 \\
\hline Public Attorney & $0.316^{*}$ & $0.612^{*}$ & -1.478 & $-0.545^{*}$ & $-0.386^{*}$ & -1.499 & $0.377^{*}$ & $0.380^{*}$ & -0.032 \\
\hline
\end{tabular}

${ }^{*} \mathrm{p}<.05$

"Age" was removed from this table since it was not statistically significant in any of the models

${ }^{+}$logistic regression; ${ }^{\#}$ OLS regression 
Table 5. Comparison of Unstandardized Coefficients Between Independent Samples for Pretrial Outcomes

\begin{tabular}{|c|c|c|c|c|c|c|}
\hline \multirow{2}{*}{ Violent Charge } & \multicolumn{3}{|c|}{ Made Bail $^{+}$} & \multicolumn{3}{|c|}{ Pretrial Incarceration $^{+}$} \\
\hline & $\begin{array}{c}\text { Male } \\
\mathrm{b} \\
-0.518^{*}\end{array}$ & $\begin{array}{c}\text { Female } \\
\text { b } \\
0.393^{*}\end{array}$ & $\begin{array}{l}\text { Z-score } \\
-5.357^{*}\end{array}$ & $\begin{array}{c}\text { Male } \\
\text { b } \\
0.730^{*}\end{array}$ & $\begin{array}{c}\text { Female } \\
\mathrm{b}\end{array}$ & Z-score \\
\hline Property Charge & $-0.459^{*}$ & $0.381^{*}$ & $-5.794^{*}$ & $0.440^{*}$ & $-0.254^{*}$ & $6.289^{*}$ \\
\hline Public Order Charge & & $0.662^{*}$ & & $0.724^{*}$ & & \\
\hline Other Charge & $0.387^{*}$ & $0.936^{*}$ & -1.398 & & $-0.638^{*}$ & \\
\hline Prior Prison Term(s) & $-0.181^{*}$ & $-0.120^{*}$ & -0.829 & $0.140^{*}$ & $0.164^{*}$ & -0.412 \\
\hline Prior Jail Term(s) & $-0.155^{*}$ & $-0.160^{*}$ & 0.164 & $0.112^{*}$ & $0.163^{*}$ & $-2.325^{*}$ \\
\hline Prior Felony Conviction(s) & $0.095^{*}$ & & & & $0.079^{*}$ & \\
\hline Prior Violent Conviction & & $0.393^{*}$ & & & $-0.334^{*}$ & \\
\hline Prior FTA Conviction & $0.326^{*}$ & $0.325^{*}$ & 0.008 & & & \\
\hline \multicolumn{7}{|l|}{ Number of Charges } \\
\hline Criminal Justice Status & $0.528^{*}$ & $0.392^{*}$ & 1.061 & $-0.704^{*}$ & $-0.636^{*}$ & -0.686 \\
\hline \multicolumn{7}{|l|}{ Black } \\
\hline Hispanic & $-1.007^{*}$ & $-0.551^{*}$ & $-2.480^{*}$ & $0.628^{*}$ & $0.249^{*}$ & $2.751^{*}$ \\
\hline \multicolumn{7}{|l|}{ Other Race } \\
\hline Private Attorney & $0.751^{*}$ & $0.850^{*}$ & -0.579 & & & \\
\hline Public Attorney & $-0.785^{*}$ & $-0.909^{*}$ & 0.257 & $0.833^{*}$ & $0.227^{*}$ & $5.655^{*}$ \\
\hline
\end{tabular}

p $<.05$

"Age" was removed from this table since it was not statistically significant in any of the models

${ }^{+}$logistic regression; ${ }^{\#}$ OLS regression 